\title{
FORMATION OF EMOTIONAL CLIMATE IN HUMAN RESOURCE MANAGEMENT
}

\author{
Sigitas VAITKEVICIUS ${ }^{1}$, Palmira PAPSIENE ${ }^{2}$ \\ 1,2 Vytautas Magnus University, Kaunas, Lithuania \\ Corresponding author e-mail: palmira.papsiene@gmail.com
}

\begin{abstract}
Research is concentrated on efficient human resource management while pursuing organizational goals and benefits for every employee and organization as a whole. Under the requirements of global market, managers expect their subordinates to be effortlessly managed, confident, dynamic in completion of assigned tasks, and ensuring maximum work efficiency. Such a possibility is theoretically analysed in this article by employing deductive thinking in interdisciplinary integration. The article describes the formation of employee emotional climate, which has impact on employee behaviour in individual as well as in team work, based on application of human resource evaluation factor with contribution of manipulations. Hypothetical presumptions resulted in assumptions that have shown dominance of disjunction (or); it means that interaction between alternatives is impossible. Therefore, logical interactions were prepared on the basis of deductive thinking by usage of Law (or principle) of the Excluded Third. These logical interactions resulted in models of emotional climate formation.
\end{abstract}

Keywords: personnel management, human resource, emotional climate, logical sequence

JEL Classification: D23, D91, M12, O15

\section{INTRODUCTION}

Efficient management of human resources is a vital factor in striving for organization's goals and benefit for every employee, organization and society. Active competitiveness in a modern market determines a rapid and versatile organizations' development related to implementation of human resource management goals. Efficient management of the available or potentially available work resources is extremely important to the organization operating in a global market.

Manager of any organization would like the employees of his enterprise would produce the best work productivity, would be easy controlled, reliable and dynamic to accomplish assigned tasks. Such variant was theoretically examined in this article by using a deductive reasoning in inter-disciplinary integration. The article describes how by invoking the factor of human resource assessment with the help of manipulations employee's emotional activity a climate can be formed that influences employee's behaviour both in individual and team work.

The aim of this research is to create interactions of the factors forming of emotional climate and human resource assessment using the empirical research, and create models of the operation of this interaction.

Methods of the research: deductive reasoning, also deductive logic, principle of logical sequence.

Copyright C 2019. Sigitas Vaitkevicius, Palmira Papsiene. Published by RTU Press

This is an Open Access article distributed under the terms of the Creative Commons Attribution License 


\section{THEORETICAL MODELING OF EMOTIONAL CLIMATE IN HRM}

An ongoing social and economic development determined many changes in organizational management, which affects the change of emotional climate. Society's increasing requirements to employees of organizations directly determine efficiency and effectiveness of implementation of social economic decisions, which results in a dis-balance of the emotional climate. Not only competencies, skills, abilities and knowledge of personnel are of big importance for decision of these problems, that's why human resources become an important value in modern organization (Jackson et al., 1995; Batra, 1996; Becker et al., 1996; Birdi et al., 2008; Kazlauskaite et al., 2008; Isoraite, 2011), but also a formation of emotional climate.

In modern human resource management, many authors consider personnel assessment as systemic activity of entire organization and the assessment isn't limited with just a single personality (Bazarova et al., 2002; Klimova, 1999). For a broader explanation of this understanding, scientific literature sometimes uses the expression "social-psychological diagnostics" (by adding an object: personality, group, organization). S. A. Lipatov (2001) notes that although specialists of psychodiagnostics analyse differences of personalities, the personality does not exist without a social environment and cannot be understood in a nonsocial context. Summarizing different approaches on the topic, he defines socialpsychological diagnostics as "assessment of social - psychological processes, states and characteristics of the personality, groups by using special diagnostic procedures, methodologies and programs" (Lipatov, 2001, p. 89).

Later, this scientific discussion was entered by I. G. Kokurina (2007), who noted that not only objective criteria (personnel turnover, discipline, labour productivity) should be used as indices, but also such subjective indices as human's attitude towards his work, motivation, etc. Later, M.V. Kaimakova (2008) expressed her opinion that in addition to employee's characteristics, it is necessary to form a potential of human resources and to create activities for personnel development, which would correspond the goals and principles of public sector organization's policy. According to the author, sometimes work control in public sector organizations is executed according to hypothetical consistency, which provides an administrative unit (a controlling person) with a positive and the employee with a negative enthusiasm in regard to working activity, which negatively affects employees' emotional climate (Papsiene, 2017). As M. Bobowik et al. (2017) noted, social and emotional climate means prevailing, relatively stable collective emotions. In the map of emotions created by V. Tran (1998), it is reflected that fear and joy are in a contraposition, but both have an impact during formation of the emotional climate.

From the discussion above we can see that human resource assessment initially was understood rather as one of the activities of human resource management, however, while scientific knowledge is deepening, more and more attention was given to identification of its structural elements. However, in parallel to these themes of human resource assessment, there was developing another one, in which the attention was given not only to a creation of taxonomy of human resource assessment components, but also to knowledge of human resource assessment as a process (Dessler, 2008; Daft, 2003; Thom et al., 2004; Ozerov, 2008; Gilley et al., 2009; Martin, 2009; Yee et al., 2009; Kaselis et al., 2012; etc.).

In this context, E. V. Maslov (1999) states that personnel assessment is a procedure with a goal to "explain how employee's personal characteristics correspond particular results of 
his activity“ (p. 218), moreover, the requirements are determined by the employee's work content and efficient activity organization. G. Dessler (2008), as well as E. V. Maslov (1999), describes personnel assessment as the procedure, however, he names other features of the procedure. These are a description of work character and types of people (in terms of knowledge and skills) and their comparison while executing a job in order the employee would correspond a working place.

The authors (Dessler, 2008; Daft, 2003; Thom et al, 2004; Arthur, 2008), describing personnel assessment process, note that there is no one opinion on assessment, methods, periodicity, time and other procedures. There is recognized the necessity for personnel assessment in striving for efficiency of personnel activity, therefore a lot of material is accumulated in this field. However, there is a lack of studies in this field, and experimental studies are of small volume. The reason of that is the absence of methodological, theoretical, consequently methodical, approaches towards personnel assessment. Without one and standardized assessment system, the assessment as the process or its approaching causes a negative reaction between employees and managers, because described assessment procedure and its progress are absent. Meanwhile, later L. Liukineviciene et al. (2009), having reviewed literature on the topic, expressed a position that essence of human resource assessment process and its result despite earlier arguments of the authors are understood almost alike, - the assessment is executed in striving for more rational use of employees, to increase their activity efficiency, work quality, to develop a personality, to create a favourable psychological climate in the collective. The author argues that favourable climate stimulates employees' mutual understanding, cooperation and informal teamwork, ant this positively affects labour productivity and activity efficiency.

In the latter position of the author, there shows up an argument, important to the problem under research, that interaction of human resource assessment and emotional climate can also explain human resource management result, and this means that, hypothetically, in their interaction a synergic or at least cumulative effect is possible, which might be expressed as any known or yet unrevealed function of human resource management. Therefore, additional research of this interaction would allow not only to answer the question how human resource assessment and emotional climate affect human resource management activity results, but also to answer the questions: why human resource assessment, which partially plays the role of the control in the organization, changes emotional climate, and if emotional climate can be managed with the help of human resource assessment function.

\section{FORMATION FORMATION OF EMOTIONAL CLIMATE BY USING A DEDUCTIVE REASONING}

In management of human resource, the assessment of employee might become a tool of employee's emotional climate formation, on which his behaviour will depend later. Human resource management may consist of $\mathrm{n}$ factors. One of these factors is a human resource assessment, by manipulating of which there is a possibility to form individually an emotional climate of each employee.

Employee's behaviour, both individual and in the group, depends on emotional climate formed to him. In this case, we will not analyse assumptions, internal sub-actions, we are interested only in a result of interaction of assumptions. By using a deductive reasoning, we'll transform assumptions into logical sequences in order to derive variations of employee's emotional climate. A principle of logical sequence states that not only 
conclusions can be made of assumptions, but assumptions can be made of conclusions as well (Pleckaitis, 2009, p. 74), that is indicated in the formula 1:

$$
\left[\left(A_{1}, A_{2}, A_{3, \cdots} A_{n}\right) \rightarrow C\right] \leftrightarrow\left[\left(A_{1} \wedge A_{2} \wedge A_{3} \wedge \cdots \wedge A_{n}\right) \rightarrow C\right]
$$

To describe a result of interaction of two assumptions, there is applied a principle of transition of implications from axioms system created by J.Łukasiewicz, with a logical operation "if..., then...," which indicates an assumption's derivation from another assumption. In this case, human resource assessment is divided into two main aspects according to so called syntactic consistency, which states that from the theory's axioms there can be derived a statement $p$ and its negative $\bar{p}$, then it is contradictory. So, the result is that $p$ is correct and $\bar{p}$ is correct. But we know that principle of contradictions does not allow to consider both statements $p$ and $\bar{p}$ as correct at the same time (Azubalis, 2008). There is created a simplified algorithm of emotional climate formation that is presented in Figure 1.

\begin{tabular}{|c|}
\hline Start \\
\hline Assumptions \\
\hline Syntactic consistency \\
\hline Logical intermediate result \\
\hline The law of excluded third \\
\hline Logical result \\
\hline End \\
\hline
\end{tabular}

Fig. 1. Structural diagram of linear algorithm

Totality of assumptions, selected and grouped on a basis of deductive reasoning, interacts and forms intermediate conclusions according to Syntactic consistency. Interactions of obtained intermediate conclusions are grouped according to the Law of excluded middle, thus obtaining the final results, this is a form of a desired emotional climate.

\section{MODELS OF EMPLOYEE'S EMOTIONAL CLIMATE}

Factors affecting an employee: one of them is a psychological bifurcation, these branches can be called as correct and incorrect branches. In this case, a psychological aspect analysed in human resource assessment could be written as follows:

$$
S \vee \bar{S} \dashv\left\{\begin{array}{l}
S \leftrightarrow(E \leftarrow F): P_{1} \\
\bar{S} \leftrightarrow(\bar{E} \leftarrow \bar{F}): P_{2}
\end{array}\right.
$$

where, $P_{n}$ - a psychological aspect of the case, where $P_{1}$ is the first branch where $F$ - fear is forming that creates $E$ - a conflicting environment in the collective. This interaction of factors forms an equivalent phenomenon $S$ - a collective disunity. In another branch $P_{2}$, there dominates an alternative of the first branch. $\bar{F}$ - a joy is forming, a collective $\bar{E}$ - a concord 
is being created. Interaction of these factors forms an equivalent phenomenon $\bar{S}$ - a collective harmony.

Material aspect in human resource assessment could be written as follows:

$$
C \vee \bar{C} \dashv\left\{\begin{array}{l}
C \leftrightarrow(B \leftarrow A): M_{1} \\
\bar{C} \leftrightarrow(\bar{B} \leftarrow \bar{A}): M_{2}
\end{array} ;\right.
$$

where, $M_{n}$ - in this case is a material aspect, where the first $M_{1}$ branch, and there is forming $A$ - a reduction in position, that creates a reason $B-$ a salary reduction. This interaction of factors forms an equivalent phenomenon $C$ - an apathy for work. In another branch $M_{2}$, there dominates an alternative of the first branch and forms $\bar{A}$ - a promotion in position, that creates a reason $\bar{B}$ - a salary increase. Interaction of these factors forms an equivalent phenomenon $\bar{C}$ - an enthusiasm for work.

Since in this case (collective disunity $S$ and collective harmony $\bar{S}$ ) are opposites as well as ( $C$ - apathy for work and $\bar{C}$ - enthusiasm for work), their interaction is impossible, therefore, there is used the Law of excluded middle. Having formed a summary of interaction of statements in psychological aspect $S \vee \bar{S}$ and material aspect $C \vee \bar{C}$, there is formed a result based on a deductive reasoning, that means, four possible emotional models of employee's activity climate $A_{\mathrm{n}}$ are being distinguished, according to a principle of logical sequence:

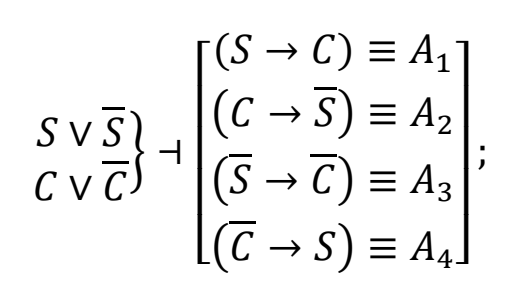

here possible emotional logical models of employee's activity climate are:

$A_{1}$ - passive individuality, a form of emotional climate where no one publicly discusses a topical question, there is no initiative for general dispute, everyone creates own opinion on the topic and expresses it only upon manager's direct inquiry.

$A_{2}$ - passive collectivity, a form of emotional climate where no one has or doesn't express a clear motivated solution on the question under consideration. The question is being discussed passingly, in a form of easy dispute that reminds a trashing over old straw, there takes place rather imitation of work, there is no clear leadership. The result is being presented by collective decision as the one that has the most beautiful sound.

$A_{3}$ - active collectivity, a form of emotional climate where a majority of employees with a clear leadership self-expression is dominating in the collective, in such collective a separation of opinions is a common phenomenon, long discussions on the solution of the topical question take place till the result is being formed. 
$A_{4}$ - active individuality, a form of emotional climate when employees with clearly expressed leadership are expressing own solution of the problem in the collective, however, without support they strive to present their decision directly to the manager personally, without collective discussions.

\section{CONCLUSION}

From interactions of assumptions there were obtained intermediate logical conclusions such as $C$ - apathy for work and $\bar{C}$ - enthusiasm for work, as well as $\bar{S}$ - collective harmony, and $S$ - collective disunity, between which there dominates a disjunction (or) which indicates that interaction between their alternatives is impossible. Therefore, having used the Law (or principle) of the Excluded Third, based on a deductive reasoning, there were created logical interactions, with help of which there were obtained logical models of emotional climate formation $\left(A_{1} ; A_{2} ; A_{3} ; A_{4}\right)$ i.e. final conclusions. We make a hypothesis that with the help of the obtained models it is possible to influence a formation of human resource emotional climate in organization, which can be formed by the manager just through manipulation of the human resource assessment factor. Created logical models will be verified during the next empirical research.

\section{REFERENCES}

Arthur, D. (2008). Performance Appraisals: Strategies for Success. New York: AMACOM.

Azubalis, A. (2008). Logika ir mokykline matematika: monografija. Vilnius: Generolo Jono Zemaicio Lietuvos karo akademija.

Batra, G. S. (1996). Human resource auditing as a tool of human resource valuation: interface and emerging practices. Managerial Auditing Journal, 11 (8), 23-30. https://doi.org/10.1108/02686909610131657

Bazarova, T. J. \& Eremina, B. L. (2002). Upravlenie personalom. Moscow: Juniti.

Becker, B. \& Gerhart, B. (1996). The impact of human resource management on organizational performance: progress and prospects. Academy of Management Journal, 39, 779-801. https://doi.org/10.2307/256712

Birdi, K., Clegg, C., Patterson, M., Robinson, A., Stride, C. B., Wall, T. D., \& Wood, S. J. (2008). The impact of human resource and operational management practices on company productivity: a longitudinal study. Personnel Psychology, 61 (3), 467-501.

Bobowik, M. Paez, D., Arnoso, M., Cardenas, M., Rime, B., Zubieta, E., \& Muratori, M. (2017). Institutional apologies and socio-emotional climate in the South American context. British Journal of Social Psychology, 56, 578-598. https://doi.org/10.1111/bjso.12200

Daft, R. (2003). Management. Mason: South - Western.

Dessler, G. (2008). A Framerwork for Human Resource Management. New York: Prentice Hall.

Gilley, A., Gilley, J. W., Quatro, S. A. \& Dixon, P. (2009). The Praeger Handbook of Human Resource Management. CA: Praeger.

Isoraite, M. (2011). Zmogiskieji istekliai - svarbiausias konkurencinio pranasumo saltinis, strategiskai valdant organizacija. Socialiniu mokslu studijos, 3(1), 31-58.

Jackson, S. E. \& Schuler, R. S. (1995). Understanding human resource management in the contex of organizations and their environments. Annual Review of Psychology, 46, $237-264$. https://doi.org/10.1146/annurev.ps.46.020195.001321

Kaimakova, M. V. (2008). Analiz ispolzovanija chelovecheskih resursov. Ulyanovsk: UlGTU.

Kaselis, M., \& Pivoras, S. (2012). Valstybes tarnautoju veiklos vertinimas pagal rezultatus: taikymo issukiai Lietuvoje. Viesoji politika ir administravimas, 11(1), 139-152. https://doi.org/10.5755/j01.ppaa.11.1.1410

Kazlauskaite, R., \& Buciuniene, I. (2008). The role of human resources and their management in the establishment of sustainable competitive advantage. Inzinerine Ekonomika-Engineering Economics (5), 78-84.

Klimova, E. A. (1999). Psihologicheskaja diagnostika v upravlenii personalom: uchebnoe posobie dlja sotrudnikov kadrovyh sluzb. Moscow: Rossijskoe psihologicheskoe obsestvo. 
Kokurina, I. G. (2007). Socialno-psihologicheskij analiz smysloobrazujushchej funkcii motivacii ziznedejatelnosti socialnogo individa. Vestnik Mosk.un-ta, ser.14, Psihologija, 1, 73-86.

Lipatov, S. A. (2001). Metody socialno-psihologicheskoj diagnostiki organizacii. Vvedenie v prikladnuju socialnuju psihologiju. Moscow: Smysl.

Liukineviciene, L. \& Garoliene, E. (2009). Studiju aplinkos personalo vertinimo kryptingumas kuriant personalo veiklos vertinimo sistema aukstojoje mokykloje. Ekonomika ir vadyba: aktualijos ir perspektyvos, 2 (15), 162-173.

Łukasiewicz, Jan (1964). Elements of Mathematical Logic. Macmillan.

Martin, J. (2009). Human Resource Management. London: Sage.

Maslov, E. V. (1999). Upravlenie personalom predprijatija. M: INFRA-M; Novosibirsk: NGAEiU.

Ozerov, M. J. (2008). Ocenka kachestva trudovogo potenciala personala kommercheskogo banka. Tomsk: Izdatelstvo VSHB Tomskij gosudarstvennyj universitet.

Papsiene, P. (2017). Human resource management efficiency problems in public sector. Mechanisms of interaction between competitiveness and innovation in modern international economic relations: collective monograph, ed. M. Bezpartochnyi. Riga: ISMA University, 126-134.

Pleckaitis, R. (2009). Logikos pagrindai. Vilnius: Tyto Alba.

Thom, N. N., \& Ritz, A. (2004). Viesoji vadyba. Inovaciniai viesojo sektoriaus valdymo metmenys. Vilnius: Lietuvos teises universiteto leidybos centras.

Tran, V. (1998). The role of the emotional climate in learning organisations. The Learning Organization, 5 (2), 99-103. https://doi.org/10.1108/09696479810212060

Yee, C. C., \& Chen, Y. Y. (2009). Performance appraisal system using multifactorial evaluation model. Proceedings of World Academy of Science: Engineering \& Technology, 41, 231-235.

\section{AUTHORS' SHORT BIOGRAPHY}

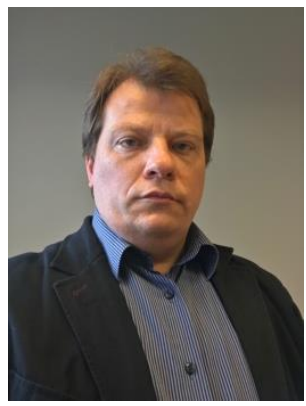

Prof. Sigitas Vaitkevicius, Ph.D. He received the Ph.D. degree from ISM University of Management and Economics. Works in Vytautas Magnus University, Faculty of Bioeconomy Development as a Senior Researcher. Universiteto str. 10-404, LT-53361 Akademija, Kaunas distr. Research interests in Strategic Management and Business \& Human Resource Research Methodology.

E-mail: sigitas.vaitkevicius@gmail.com

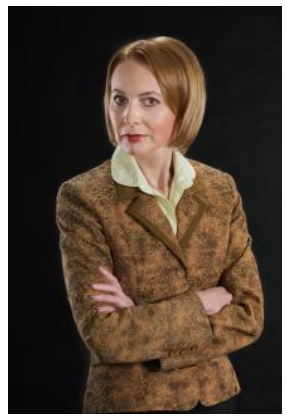

Palmira Papsiene is Vytautas Magnus University Agriculture Academy of Business and Rural Development Research Institute member of the science research group. Universiteto str. 10-404, LT-53361 Akademija, Kaunas distr. Main research areas include Organizational Behavior, Human Resources Management. Works have been published in various national and international conferences and research papers.

E-mail: palmira.papsiene@gmail.com 